\title{
Two Parallel life Paths: Aladár ÁrKay ANd Ernő FoerK
}

\author{
Aurél Benárd \\ Szent István University Ybl Miklós Faculty of Architecture and \\ Civil Engineering \\ Institute of Architecture, Budapest, Hungary \\ Benard.Aurel@ybl.szie.hu
}

\begin{abstract}
Architects Aladár Árkay and Ernö Foerk crossed the path reasonable few times, even though their course of life were parallel. Not only the place, but also the date of their birth were quite close. This fact will be the starting point to compare the two architects'career.
\end{abstract}

Keywords: Árkay, Foerk, church architecture, Historicism, Art Nouveau, Modern

\section{THEIR MASTERS}

Aladár Árkay and Ernő Foerk were born in Timisoara in 1868. Árkay on February 1 (died on February 2 1932), Foerk on February 3 (died January 26 1936). This seems a fateful coincidence and the parallels do not end there, even though next year Sándor Árkay and his family moved to Pest and they lose contact to Timisoara. [1]

Both started their career with a strong artistic motive. While the two days older Árkay was obsessed with painting, Foerk was attracted to sculpture. Vienna, the Imperial City, became a reference point in their professional life - Foerk was studying there, Árkay was working as a construction supervisor for the studio of the celebrated Viennese theatre architects Fellner \& Helmer.

The two different minded architects they worked at determine their further professional progress. Foerk is in the employ of Imre Steindl, a rather purist architect whose design style turns from Neo-Renaissance to Neo-Gothic. Foerk participates in the design of the Parliament Building in Budapest. Meanwhile Árkay is working with Alajos Hauszmann at the construction of the Royal Palace in Buda, also a building representing authority. Hauszmann's workstyle is rather experimental. His building style developed from Neo-Renaissance to Art Nouveau, his work reflects the completely new, almost revolutionary concept of architecture at the end of the 19th century. At that time, the expressions of architecture used to be adopted from the historical architecture, in an academic way. Although there have been attempts to create a new style for a „modern” architecture (e.g., favourite examples of mine are the form-and-structure experiments of Viollet le Duc), but this long-sought modern style could only evolve at the end of the century in cultures belonging to the West. Hauszmann recognized the potential of this new architecture and might have give encouragement to Árkay. I do not see this openness in Steind's work, and this conservative approach characterised later on Foerk's design attitude.

However, the various approach has not to be considered as a difference in the professional quality of Hauszmann and Steindl. Currently we more appreciate the individual performance, the analytical approach, the personalities looking for new ways - but we need to relate and rely 
on our past as well. It is more a difference in habit; obviously, also the reason for the of Foerk's and Árkay's different choice of workplace at the beginning of their career.

\section{THE WAY TO THE OWN ARCHITECTURE PRACTICE}

In the light of the foregoing Aladár Árkay is an experimenting architect. Although at Hauszmann's office and later in the studio of his father in law, Mór Kallina he is still working in Neo-Renaissance style, he is not left untouched by the architecture of Ödön Lechner. At the turn of the century he is designing an ensemble of two buildings at the corner of Dózsa György út - Andrássy út in Budapest (1905); one of them, the villa of Babochay displays the characteristics of Lechner's Hungarian Art Nouveau. (This building was reconstructed in the forties by Lajos Kozma in a completely different style). However, he was also influenced by the Wiener Werkstätte and the National Romanticism in Finland, thus of the Hungarian Art Nouveau, in particular the work of the Group of the Young led by Károly Kós. Árkay's highly sophisticated building, the Fasori Reformed Church markedly reflects this impact; buit in 1913 - the year when Ernö Foerk took over the design of the Szeged Votive Church from Frigyes Schulek. It is worth to take a moment at the Fasori Reformed Church - Árkay's early, emblematic work of high complexity. While its form is a Byzantine (greek cross and a dome), its ornamental decoration is primarily connected to the Wiener Werkstätte; the main facade is linked to the idea of Finnish national romantic style. The church's rectangular tower contributes to this dissonancy. It looks oversized to the building and plays clearly a different tone. The vertically structured facade and the retracted upper storey recall the Italian San Marco Campanile in Venice. Schulek and Foerk used the same analogy to design the towers of the Votive Church of Szeged; however, the towers here are more organically connected.

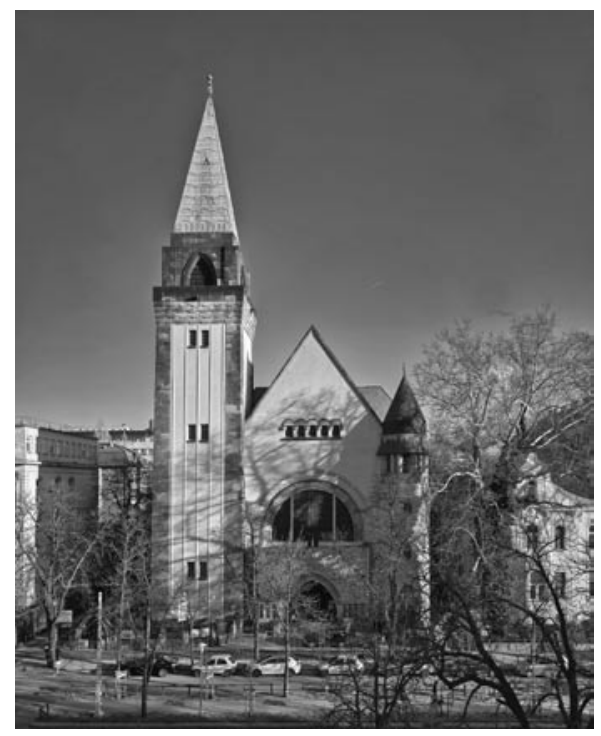

Figure 1. Fasori Reformed Church Budapest (Photo: Klein, Rudolf)

As lecturer at the Magyar Királyi Állami Felsö Épitö Ipariskola (Hungarian Royal Public Higher Architectural Industrial School) in Budapest, Foerk lead a survey of monuments from the Renaissance time in Upper Hungary (Felvidék - today in Slovakia) and Transylvania (Erdély - today in Romania). [2] In 1918, he makes a study trip visiting mainly orthodox monasteries in Montenegro. 


\section{POSTWAR CRISIS}

The end of World War I leave the remnant of the former monarchy in a profound crisis. The construction of the Votive Church in Szeged get stock. Architects are struggling to find any job; Árkay is also in crisis. A reflection of this period might be seen in the design of the Mohács Votive Church made by Árkay, which is a domed church in Byzantine - Historicizing style. The key element of the three-level dome forms the Hungarian crown with the oblique cross at its apex. Such a direct, loud, almost brilliant display of the symbol is not suspected to be Árkay's intention - the name of the client, Dr. Gyula Zichy, Archbishop of Kalocsa, appears in large letters on the plan.

Also characteristic for its age is the so called Small Church at Városmajor (Városmajori Kistemplom) built in 1922-23. The population of the capital was dynamically growing because the massive move-in of people escaping from the displaced areas - and this gave also the necessity for the construction of the church. Árkay recalls the medieval church architecture, with a link to the National Romanticism in Finland; but at the same time, he design a church dedicated to the vernacular architecture of Transylvania, an area displaced as result of the Treaty of Trianon. The Small Church at Városmajor was built 15 years after the church in Zebegény designed by the architects Károly Kós and Béla Jánszky.

\section{THE WESTERN EUROPEAN TOUR}

In 1925 Aladár Árkay goes on a study trip - later and in the opposite direction then Foerk. It is a Western European tour - he visits among others Vienna, Germany, the Netherlands, Belgium and France. He reports about his travel, experiences and thoughts in several articles. [3] He introduce a very broad spectrum of architecture from the Art Nouveau through the German Expressionism and reports enthusiastically on architectural ideas of the followers of Frank Lloyd Wright and the radical appearance of the Classic Modern. He first illustrates the change of the world with examples from the fine arts; he analyses works of German expressionist sculptors, such as Max Beckmann and Wilhelm Lehmbruck.

The Town Hall in Mohács or the Church in Györ Gyárváros (east part of the city Györ) designed by Árkay demostrate the impact of the representatives of the Expressionist Architecture like the vaguely Expressionist concrete Lindenhaus, Berlin-Kreuzberg (1912-13) by P. Zimmerreimer and O. R. Salvisberg. Árkay visits the newly built row of Rue du Cubisme in Brussels-Koekelberg by the architect Victor Bourgeois [4], who later design the Weissenhof Siedlung Belgium in Stuttgart (1922). The Netherlands architecture has a big impact on Árkay - interestingly there is not any note about any of the churches here, although the church architecture of the Modern is rooted in the Netherlands (St Hubertus church, Maastrich) [4]. However, in France he is fascinated by the church in Raincy; this masterpiece of the concrete Gothic by Auguste Perret.

\section{THE ARCHITECTS OF CHURCHES}

While Árkay is following the new ideas with great interest, Foerk is building in the spirit of the 19th century, a medieval builder like (Bauhütte). Shortly after the Votive Church of Szeged was dedicated (1930), the so-called Great Church at Városmajor (Városmajori Nagytemplom) was built - by Aladár Árkay and his son Bertalan (1931-33) - as Aladár Ârkay died in 1932 Bertalan has to complete. 
Without his father's openness, this church of Behrens's expressionist style and forms of Italian Rationalism would not have been constructed.

Mihály, the son of Ernő Foerk also become an architect; his father is delighted about his son's interest. But Mihály falls on the front in the World War I.

Gyula Rimanóczy, the designer of the Franciscan Church in Pasarét is welcoming the design of the Great Church at Városmajor with enthusiasm. However later, Rimanóczy's design is strongly opposed by Gyula Petrovácz, who is a permanent co-worker of Foerk's at their ecclesiastical assignments. [5] Based on Petrovácz's his opinion about Árkay's Great Church is conceivable dismissive. Although Foerk might not have been neither as impulsive as his colleague, nor a public figure yet this affair is a good indication of the difference in professional attitude of Árkay and Foerk and the contrast of their way of life.

\section{CONCLUSION (POST SCRIPTUM)}

Finally, a late parallel: Aladár Árkay’s son, Bertalan also built several churches, even in his declining period, after the World War II. At these works we can discover motifs, details as if he were paying tribute to his father's work or remembering on their common work. From his late works, the Parish Church of Hort is outstanding. Its eastern facade is the gable wall of the rectangle sanctuary. On the gable a rounded central window is surrounded by seven smaller circular windows. This motif is that we see at the gables of the cross nave of the Szeged Votive Church [6] [7], and later on the main facade of the Roman Catholic Churches in Vállaj and in Fajsz. The central window at the Parish Church in Szeged is even shaped like a rose window. This early type of rose windows, such as at Limburg an der Lahn or Chartres have normally eight smaller circular windows surrounding the larger central one. However, this seven surrounding circular windows I have ever seen at works of Ernö Foerk and Bertalan Árkay's church in Hort. This motif could be conceived of as a gesture of religious love and faith to a former colleague.

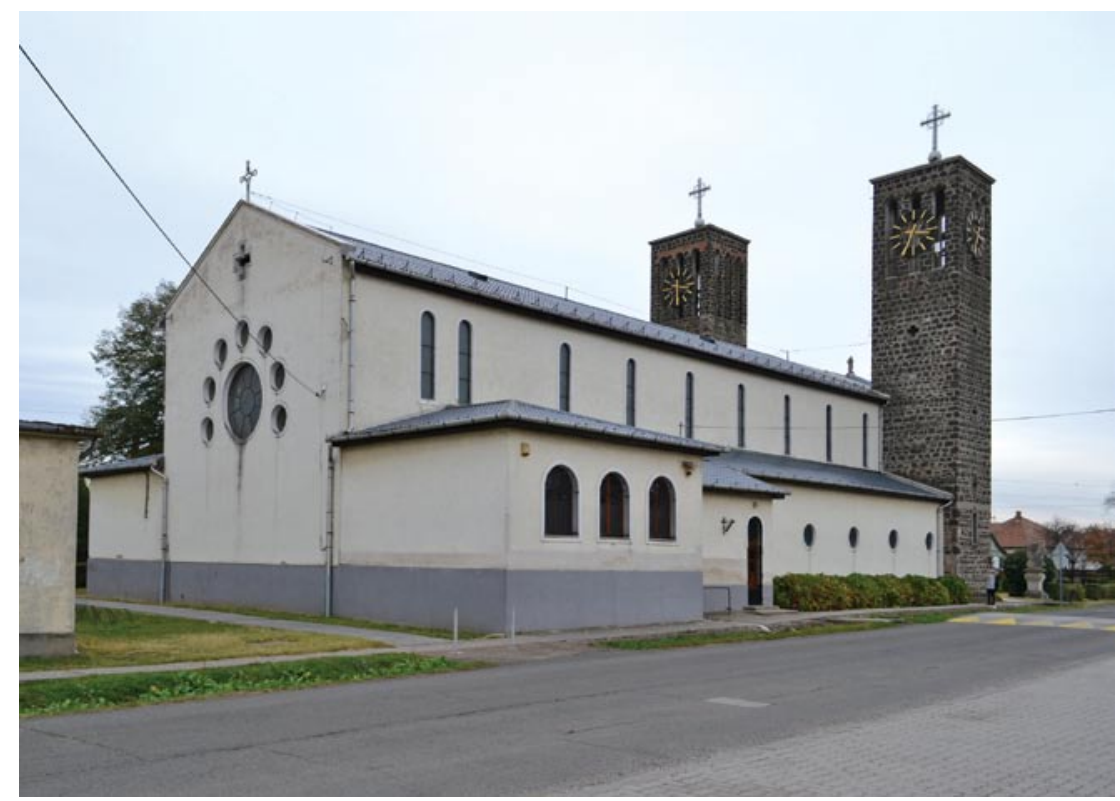

Figure 2. Parish Church Hort, Sanctuary (Author's photo) 


\section{REFERENCES}

[1] Dercsényi, Balázs. Árkay Aladár. Budapest: Akadémiai Kiadó, 1967.

[2] Foerk, Ernő, [szerk.]. A Magyar Királyi Állami Felső Építő Ipariskola Szünidei Felvételei (reprint). Budapest: Terc Kft., 2002.

[3] Árkay, Aladár. Építő formák a világháború után. Kö- és mükő architektúra. Temetőmüvészeti, szobrászati és épitészeti haviszemle, 13, 1926..: pp 2-4.

[4] Strauven, Iwan. Victor Bourgeois 1897-1962. Modernity, tradition \& neutrality. Rotterdam : Nai010 uitgevers, 2018.

[4] Pamer Nóra: Magyar építészet a két világháború között Müszaki könyvkiadó Budapest, 1986, p 132..

[5] Csaba, Rezső. A pasaréti templom és a szovjet stílus, Építőmunka. 1933., vol 6-7.., pp.: 102106

[6] Az O.M.F. Magyar Építészeti Múzeumának kiállítása Foerk Ernő (1868-1934) építész műveiből, ed.: András, Hadik, László, Pusztai, OMF Budapest, 1984. Figure 22. Szeged Fogadalmi templom kiviteli terve, 1904. Kat: 67. p 35., Figure 20. Budapest, Szent Imre templom és kollégium terve 1910. Kat: 60. p 31.

[7] Farbakyné Deklava Lilla: Schulek Frigyes Holnap Kiadó Budapest, 2017, pp 180-181. 